\title{
Assessment of Groundwater Quality Status for Irrigation in Thal Area
}

\author{
Mohammad Shafiq ${ }^{1 *}$, Abdul Ghaffar Sagoo², Mohammad Arif ${ }^{3}$, Mohammad Yousaf ${ }^{2}$, Mohammad Zafar ${ }^{2}$, Naeem $^{2}$ \\ Akhtar $^{2}$, Khalid Nazir ${ }^{4}$ and Abdul Hannan ${ }^{5}$ \\ ${ }^{1}$ Department of Irrigation, Pakistan
}

${ }^{2}$ Farm Manager Thal Sub-Division, Pakistan

${ }^{3}$ Reclamation Supervisor Thal Sub Division, Pakistan

${ }^{4}$ ALRO Chakkanwali Reclamation Farm, Pakistan

${ }^{5}$ ALRO LJC Sargodha, Pakistan

*Corresponding author: Muhammad Shafiq, Department of Irrigation, Pakistan

\begin{abstract}
The problem of ground water quality has become more imperative than the quantity, as the ecological glitches are getting more severe in various zones of the globe. Numerous factors such as pollution due to agricultural, industrial and human activities, poor groundwater governance and other ecological surroundings in which the water ensues to stay or move and intermingle with ground and living organisms. These impacts prominently on the ground water quality of specific zone. Therefore, a field study was planned in Land Reclamation Sub-Division Thal in 2016 to assess the quality of ground water being pumped. Thal Sub-Division includes Layya, Kundian, Ahmad Pur Sial and Bhakkar districts. Overall 370 water samples each in pre and post Mon soon season 2016 were collected. The water samples were analyzed for their quality characteristics. Data for quality of irrigation were analyzed, from electrical conductivity (EC) point of view : fit $\left[\left(E C<1 \mathrm{dS} \mathrm{m}^{-1}\right)\right.$, marginally fit $\left(E C=1-1.25 \mathrm{dS} \mathrm{m}^{-1}\right)$ and unfit $\left.\left(E C>1.25 \mathrm{dS} \mathrm{m}^{-1}\right)\right]$; from residual sodium carbonate (RSC) point of view, fit (RSC $<1.25 \mathrm{me} \mathrm{L}^{-1}$ ), marginally fit ( $\mathrm{RSC}=1.25-2.5 \mathrm{me} \mathrm{L}^{-1}$ ) and unfit (RSC $\left.>2.5 \mathrm{me} \mathrm{L}^{-1}\right)$ and in case of sodium adsorption ratio (SAR), fit (SAR $\left.<6 \mathrm{mmol} \mathrm{L}^{-1}\right)^{1 / 2}$, marginally fit $\left(\mathrm{SAR}=6-10 \mathrm{mmol} \mathrm{L}^{-1}\right)^{1 / 2}$ and unfit $\left(\mathrm{SAR}>10 \mathrm{mmol} \mathrm{L}^{-1}\right)^{1 / 2}$. The results indicated that $47 \%$ water samples were found unfit in the study area for irrigation purpose. The deleterious effects of salts could be mitigated by mixing of brackish water with canal water in different extents and/or spasmodic flushing of soil profile with decent feature irrigation water. This practice may be carried out periodically to avoid economic yield losses.
\end{abstract}

Keywords: Brackish water; Thal area Bhakkar; EC; SAR; RSC; Ground water

\section{Introduction}

Water plays the all-important role for successful cultivation of crops under an arid and semi-arid environment. The agriculturally productive areas are consistently subjected to continuously or intermittent non-availability of water during the crop growth. Pakistan is also facing the similar situation, as its most part lies in an arid environment [1]. During the most part of the season, sufficient quantity of good quality canal water is not available for exploiting the potential yield of crops. Thereby, ground water resources are utilized to meet the wholly or partial demand of crop. Umair et al.
[2] reported that in most of the cases, the quality of ground water resources for irrigation purpose is un-fit for crop production and produces negative impacts on productivity of crops. Ishaq et al. [3] enumerated that $75 \%$ of the tube wells installed in Sahiwal area are extracting water, which is unfit for direct application as irrigation water and needed appropriate treatments prior to application to reduce the deleterious effects of salts for sustaining crop production. Salinization of soils is a major threat to agriculture, which is being further aggravated by irrigating the soils with poor 
quality groundwater. It has been monitored that ground waters being taken from district Multan differed greatly in its chemical composition and 58\% water samples were analyzed as unfit for irrigation purpose [4].

Corresponding to this, the proportion of quality of irrigation water varied in terms of 35\% unfit, $27 \%$ marginally fit and $38 \%$ fit for irrigation use in district Layyah [5]. Various workers quoted that out of the total, $48 \%$ and $76.6 \%$ installed tube wells in districts Gujrat and Lahore, respectively, were pumping water unfit for irrigation use [6,7]. Likewise, Mehboob et al. [8] pointed out that ground water being pumped in Chunian, Pattoki, Kot Radha Kishan and Kasur areas was 60\%, 90\%, 90\% and 86\%, respectively, classified as unfit for irrigation.

This study further concluded that $97 \%$ water samples were unfit due to EC (1.25 dS m $\mathrm{m}^{-1}$ ), 63\% (SAR > $\left.10 \mathrm{mmol} \mathrm{L}^{-1}\right)^{1 / 2}$ and $97 \%$ (RSC> $2.5 \mathrm{me} \mathrm{L}^{-1}$ ) among the lot. The irrigation water having too much concentration of chloride, sulphate, bicarbonate, sodium, calcium, magnesium, potassium and nitrates causes not only reduction in the fertility of soils, but also alleviating the economic yield [9]. The reduction in yield is in proportion to alone and/or combined action of these ions on stage of plant growth and crop varieties [10]. This may be due to the reason that surplus salts lessen the ability of plant to absorb water and causes stunted vegetative and root development. Burman et al. [11] concluded that yield of many crop plants may be reduced by 50-70 \%, because of higher amounts of toxic salts. Apart from surveys conducted in other parts of the province, a little documented data is available about the quality of water being pumped in Thal area. The farmers resort to apply tube well water during the short supply of good quality canal water. Therefore, a research plan was framed to find out the quality status of water being pumped by the tube wells in Thal Sub-Division Bhakkar.

\section{Materials and Methods}

Extensive water quality sampling was necessary to understand chemical composition and evaluate water quality for irrigation use. Present study was planned to get groundwater samples for their chemical analysis for irrigation purpose. In this survey 370 water samples were taken (including 160 from Bhakkar, 120 from Layyah, 40 from Ahmad Pur Sial and 50 from Kundian area of Thal SubDivision) by maintaining 6 * 6 KM grid during each in Pre and Post Monsoon Season 2016 and the average values of these two seasons were discussed as there was no change in the suitability of these samples in both the seasons (Table 1). The water samples were collected from running tube wells in clean plastic bottles. On an average, the bore depth of tube wells was about 110 feet. Map 1 shows the GPS (global positioning system) of the selected tube well points with respect to EC. Collected water samples were analyzed in the laboratory at room temperature for the chemical parameters such as electrical conductivity (EC), soluble cations $\mathrm{Ca}^{2+}, \mathrm{Mg}^{2+}, \mathrm{Na}^{+}$ and anions $\mathrm{CO}_{3}{ }^{2-}, \mathrm{HCO}_{3}$; , and $\mathrm{Cl}^{-}$as described by Page et al. [12]. Whereas Sodium Adsorption Ratio (SAR), and Residual Sodium Carbonate (RSC) were calculated as follows

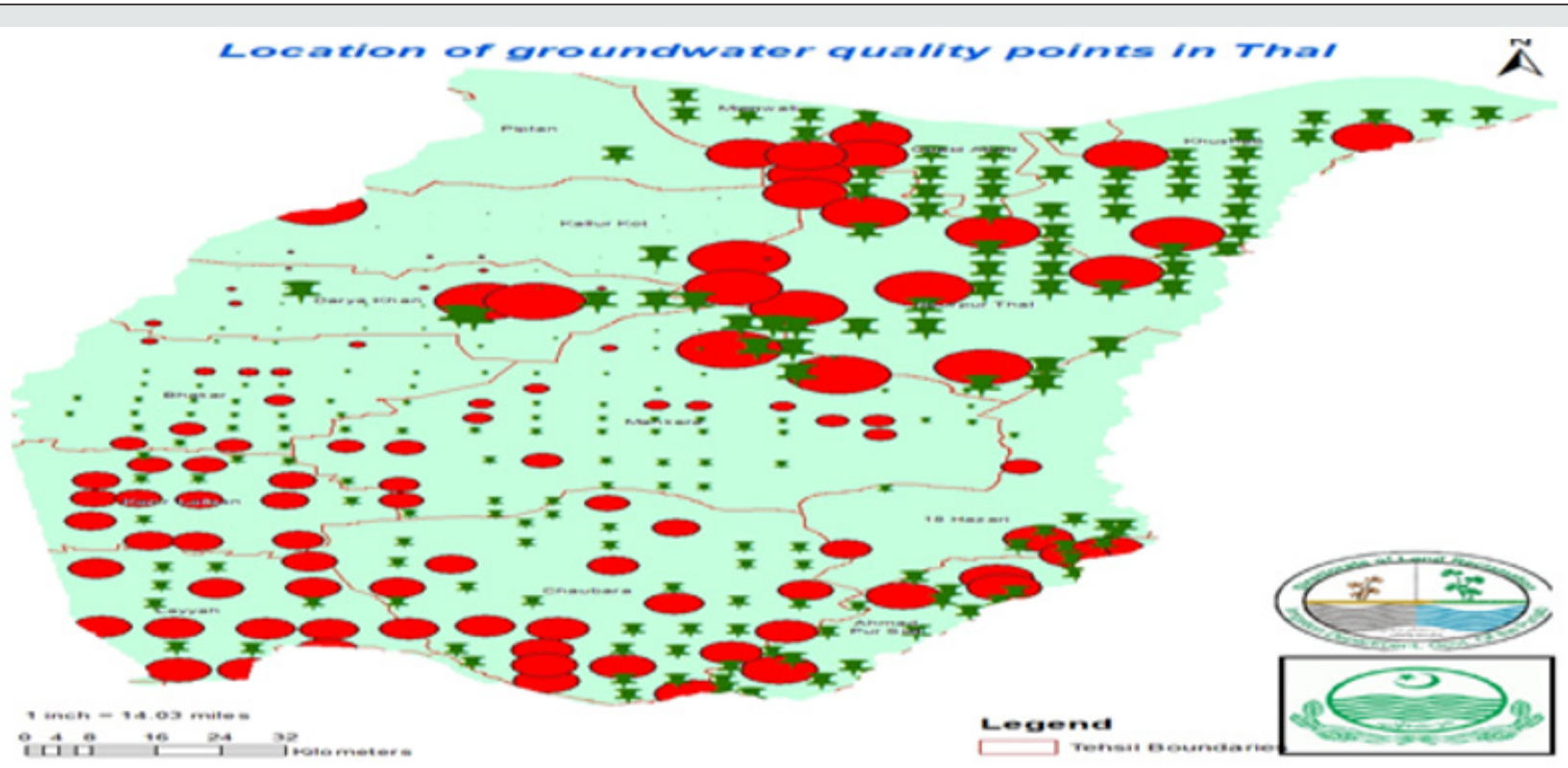

Map 1: Fit, unfit and marginally fit points in Thal sub-division Bhakkar for the year 2016.

Table 1: Criteria for quality of irrigation water.

\begin{tabular}{|c|c|c|c|}
\hline Status & $E C\left(d S ~ m^{-1}\right)$ & SAR $\left(\mathrm{mmol} \mathrm{L}^{-1}\right)^{1 / 2}$ & $\operatorname{RSC}\left(\mathrm{me} \mathrm{L}^{-1}\right)$ \\
\hline Fit & $<1.0$ & 6 & $<1.25$ \\
\hline Marginally Fit & $1-1.25$ & 10-Jun & $1.25-2.5$ \\
\hline Unfit & $>1.25$ & $>10$ & $>2.5$ \\
\hline
\end{tabular}

Source: Malik (1984). 


$$
\begin{aligned}
R S C & =\left(\mathrm{CO}_{3}{ }^{2-}+\mathrm{HCO}_{3}{ }^{1-}\right)-\left(\mathrm{Ca}^{2+}+\mathrm{Mg}^{2+}\right), \\
\frac{\mathrm{Na}}{S A R} & =\frac{\sqrt{\mathrm{Ca}+\mathrm{Mg}}}{2}
\end{aligned}
$$

Table 2 shows the textural composition of the study area. Taking into account textural classification ground water quality goes on deteriorating from Kundian to Bhakkar and so on to Layyah and the poorest ground water quality exists in Ahmad Pur Sial.

Table 2: Textural analysis of different areas, Thal sub-division Bhakkar.

\begin{tabular}{|c|c|c|c|c|}
\hline Location & Sand (\%) & Silt (\%) & Clay (\%) & Textural Class \\
\hline Kundian & 70 & 23 & 7 & Loamy Sand \\
\hline Bhakkar & 65 & 25 & 10 & Loamy Sand \\
\hline Layyah & 61 & 24 & 15 & Sandy Loam \\
\hline Ahmad Pur Sial & 50 & 32 & 18 & Sandy Loam \\
\hline
\end{tabular}

\section{Results}

\section{Electrical Conductivity (EC) of Groundwater}

Figure 1 explains that out of 370 groundwater samples 70 from Bhakkar, 50 from Layyah 12 from Ahmad Pur Sial and 21 water samples from Kundian were found fit for irrigation purpose.
Whereas, 17,15,3 and 7 no of samples were marginally fit for irrigation from Bhakkar, Layyah, Ahmad Pur Sial and Kundian respectively. Out of 370 water samples collected from different tube wells of Thal Sub-division 73 from Bhakkar, 55 from Layyah, 25 from Ahmad PurSial and 21 from Kundian were found unfit for irrigation.

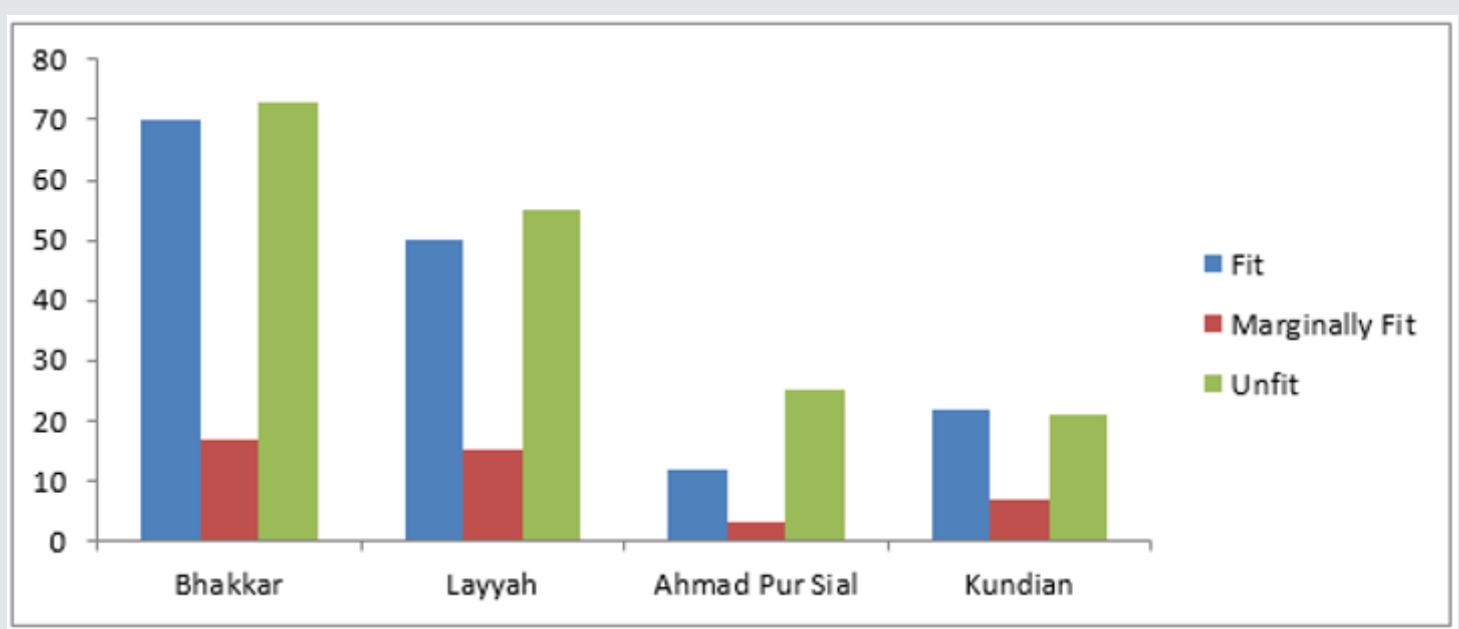

Figures 1: Fit, unfit and marginally fit points in Thal sub-division Bhakkar for the year 2016.

\section{Sodium Adsorption Ratio}

The extent to which the irrigation water tends to be involved in cation exchange reaction in soil can be specified by the sodium adsorption ratio, since sodium reinstates adsorbed calcium and magnesium in soil [13]. Out of the total unfit (174) water samples 33 were unfit (Table 3) due to higher values of both EC and SAR in Thal sub Division. Table 4 explains that in Bhakkar the values of SAR ranged from 0.25 to $16.6\left(\mathrm{mmol} \mathrm{L}^{-1}\right)^{1 / 2}$ with a mean value being $6.13\left(\mathrm{mmol} \mathrm{L}^{-1}\right)^{1 / 2}$ (Table 4). In case of Layyah area the values of SAR ranged from 0.25 to $29.7\left(\mathrm{mmol} \mathrm{L}^{-1}\right)^{1 / 2}$ with a mean value of $6.78\left(\mathrm{mmol} \mathrm{L}^{-1}\right)^{1 / 2}$. While in Ahmad Pur Sial area the SAR values ranged from 1.24 to $14.62\left(\mathrm{mmol} \mathrm{L}^{-1}\right)^{1 / 2}$ with a mean value of $6.00\left(\mathrm{mmol} \mathrm{L}^{-1}\right)^{1 / 2}$. In Kundian area the SAR values varied from 0.20 to $13.15\left(\mathrm{mmol} \mathrm{L}^{-1}\right)^{1 / 2}$ with a mean value of $5.28\left(\mathrm{mmol} \mathrm{L}^{-1}\right)^{1 / 2}$. Map 2 gives an excellent idea of groundwater quality points in Thal with respect to SAR.

\begin{tabular}{|c|c|c|c|c|c|c|c|c|}
\hline Location & EC & SAR & RSC & EC+ SAR & $\mathrm{EC}+\mathrm{RSC}$ & SAR+RSC & EC+SAR+RSC & TOTAL \\
\hline Bhakkar & 14 & 12 & 14 & 15 & 6 & 3 & 9 & 73 \\
\hline Layyah & 21 & 4 & 1 & 16 & 2 & 3 & 8 & 55 \\
\hline A. P. Sial & 5 & - & 14 & - & - & 1 & 5 & 25 \\
\hline Kundian & 7 & 3 & 1 & 2 & 2 & 3 & 3 & 21 \\
\hline Total & $47(27 \%)$ & $19-11 \%$ & $30-17 \%$ & $33(19 \%)$ & $10(6 \%)$ & $10(6 \%)$ & $25(14 \%)$ & 174 \\
\hline
\end{tabular}

Table 3: Detail of unfit water samples with respect to EC, SAR, RSC and cumulative effects of these parameters in 2016. 
Table 4: Detail of unfit water samples with respect to EC, SAR, RSC and cumulative effects of these parameters in 2016.

\begin{tabular}{|c|c|c|c|c|}
\hline Parameters & Bhakkar & Layyah & Kundian & Ahmad PurSial \\
\hline \multicolumn{5}{|c|}{$E C\left(d S ~ m^{-1}\right)$} \\
\hline Minimum & $0.40\left(0.78 \mathrm{~kg}^{2}\right.$ salt ha $\left.{ }^{-1}\right)$ & $0.25(0.487 \mathrm{~kg}$ salt $/ \mathrm{ha})$ & $0.32(0.623 \mathrm{~kg}$ salt $/ \mathrm{ha})$ & $0.32(0.623 \mathrm{~kg}$ salt $/ \mathrm{ha})$ \\
\hline Maximum & $2.1\left(4.1 \mathrm{~kg}\right.$ salt ha $\left.{ }^{-1}\right)$ & $6.86\left(13.4 \mathrm{~kg}\right.$ salt ha $\left.^{-1}\right)$ & 2.79 (5.44 kg salt/ha & $1.8(3.51 \mathrm{~kg}$ salt/ha) \\
\hline Standard Deviation & 0.44 & 1.1 & 0.62 & 0.42 \\
\hline Average & 1.14 & 1.49 & 1.08 & 1.01 \\
\hline \multicolumn{5}{|c|}{ SAR $\left(\mathrm{mmol} \mathrm{L}^{-1}\right)^{1 / 2}$} \\
\hline Minimum & 0.25 & 0.25 & 0.2 & 1.24 \\
\hline Maximum & 16.6 & 29.7 & 13.15 & 14.62 \\
\hline Standard Deviation & 4.7 & 5 & 4.35 & 3.57 \\
\hline Average & 6.13 & 6.78 & 5.28 & 6 \\
\hline \multicolumn{5}{|c|}{$\operatorname{RSC}\left(\mathrm{me} \mathrm{L}^{-1}\right)$} \\
\hline Minimum & 0 & 0 & 0 & 0 \\
\hline Maximum & 8 & 5.4 & 5.32 & 7.1 \\
\hline Standard Deviation & 1.21 & 1.1 & 1.28 & 1.96 \\
\hline Average & 1.33 & 0.58 & 0.78 & 2.29 \\
\hline
\end{tabular}

${ }^{*} \mathrm{EC}\left(\mathrm{dSm}^{-1}\right) \times 640=\mathrm{mg} \mathrm{L}^{-1}$ and 1-acre foot irrigation water $=198 \times 220 \times 1=43560$ cubic feet One cubic feet $=28.3$ liters, 1 -acre foot $=43560 \times 28.3=1232748$ liters Parts per million $(\mathrm{ppm})=1 \mathrm{mg}$ or $10^{-6} \mathrm{~kg} \mathrm{~L}^{-1}$. So, 1 -acre foot irrigation $=10^{-6} \times 1232748=1.23275 \mathrm{~kg}$ salts, OR I hectare foot irrigation $=3.04488 \mathrm{~kg}$ salt ha-1.

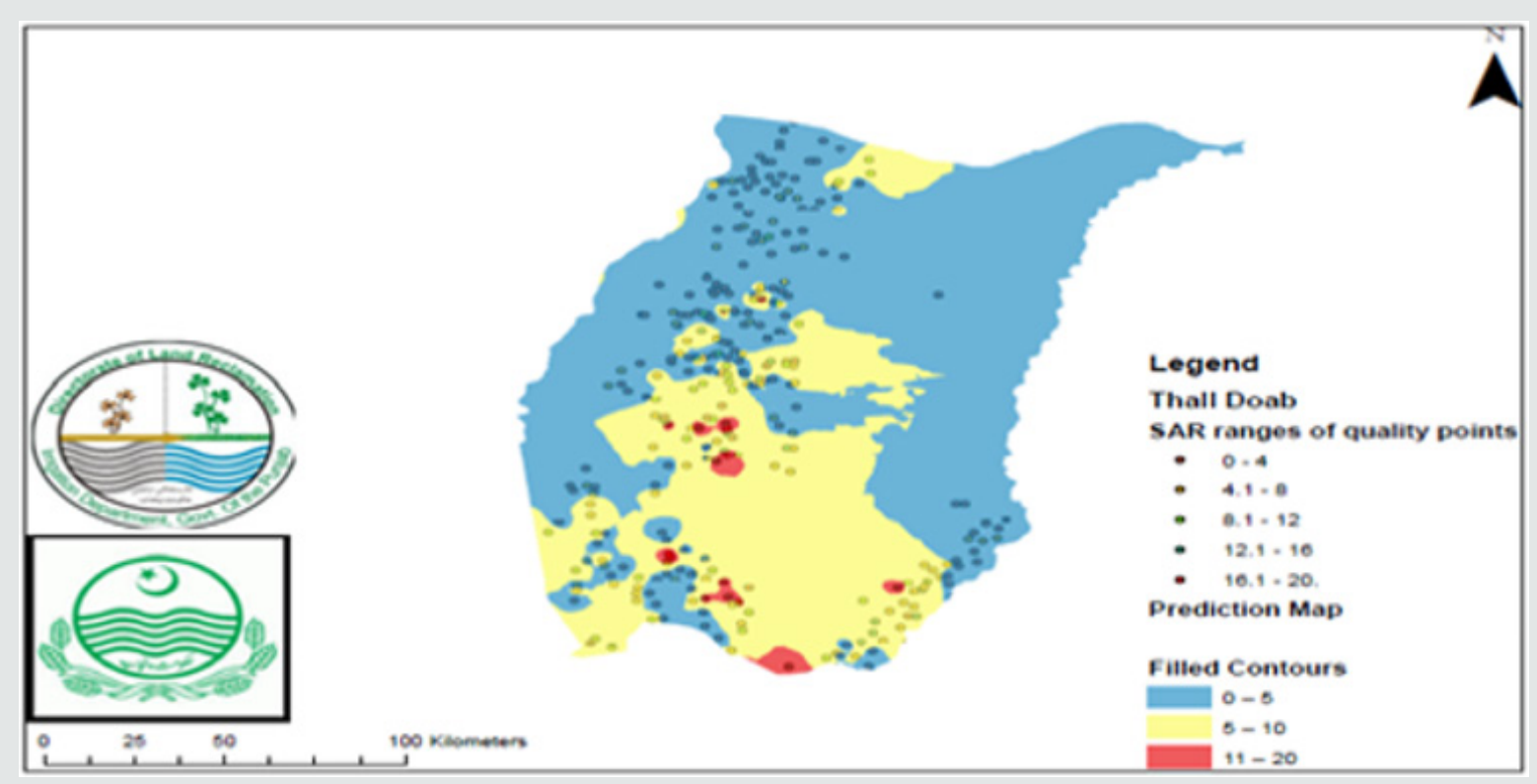

Figures 2: GPS map of the quality points with respect toSAR in the Thal area.

\section{Residual Sodium Carbonate (RSC) of Groundwater}

Out of the total 174 unfit water samples in Thal area30 were unfit solely due to high values of RSC (Table 3). The values of RSC ranged from 0.00 to $8.00 \mathrm{me} \mathrm{L}^{-1}$ and a mean value of $1.33 \mathrm{me} \mathrm{L}^{-1}$ in Bhakkar area (Table 4). Whereas, in Layyah RSC values varied from 0.00 to $5.40 \mathrm{me} \mathrm{L}^{-1}$ and a mean value of $0.58 \mathrm{me} \mathrm{L}^{-1}$. In case of Ahmad Pur Sial the values of RSC ranged from 0.0 to $7.10 \mathrm{me}$ $\mathrm{L}^{-1}$ and a mean value of $2.29 \mathrm{me} \mathrm{L}^{-1}$ and in Kundian minimum and maximum RSC values varied from 0.00 to $5.32 \mathrm{me}^{-1}$ respectively with a mean of $0.78 \mathrm{me} \mathrm{L}^{-1}$. Whereas, 25 water samples were unfit due to the cumulative effect of EC, SAR and RSC (Table 3). Map 3 shows distribution of groundwater quality points in Thal area with respect to RSC.

\section{Discussion}

The results (Table 3) show that majority of groundwater samples $(27 \%)$ taken from the area were not suitable for irrigation because of higher electrical conductivity values, however, causing no sodicity problem insight. The reason being that soils of Thal subdivision are medium textured, alluvial in nature and contain high content of $\mathrm{CaCO}_{3}^{-2}$ and saline groundwater of the area [14]. There are estimates that presence of higher EC may result in the buildup 
of salts from 565.11 to $31,131.0 \mathrm{~kg}$ salts $\mathrm{ha}^{-1}$ [15]. Table 4 shows the addition of salts $\left(\mathrm{kg} \mathrm{ha}^{-1}\right)$ per irrigation of groundwater in study area of Thal sub-division Bhakkar. Pervaiz et al. [6] suggested that irrigation water having EC up to $4.5 \mathrm{dS} \mathrm{m}^{-1}$ could be used safely on light and medium textured soils by avoiding any significant reduction in most of crop yields. In general, water containing EC less than $0.75 \mathrm{dS} \mathrm{m}^{-1}$ may not cause any problem of salinization and is suitable for irrigation purpose. The findings of this study agree with results of many other researchers $[6,7,16]$ that quality of ground water was quite inconsistent with regard to irrigation purpose. About $70 \%$ of tube well water in the Punjab province is unfit for irrigation use [17].

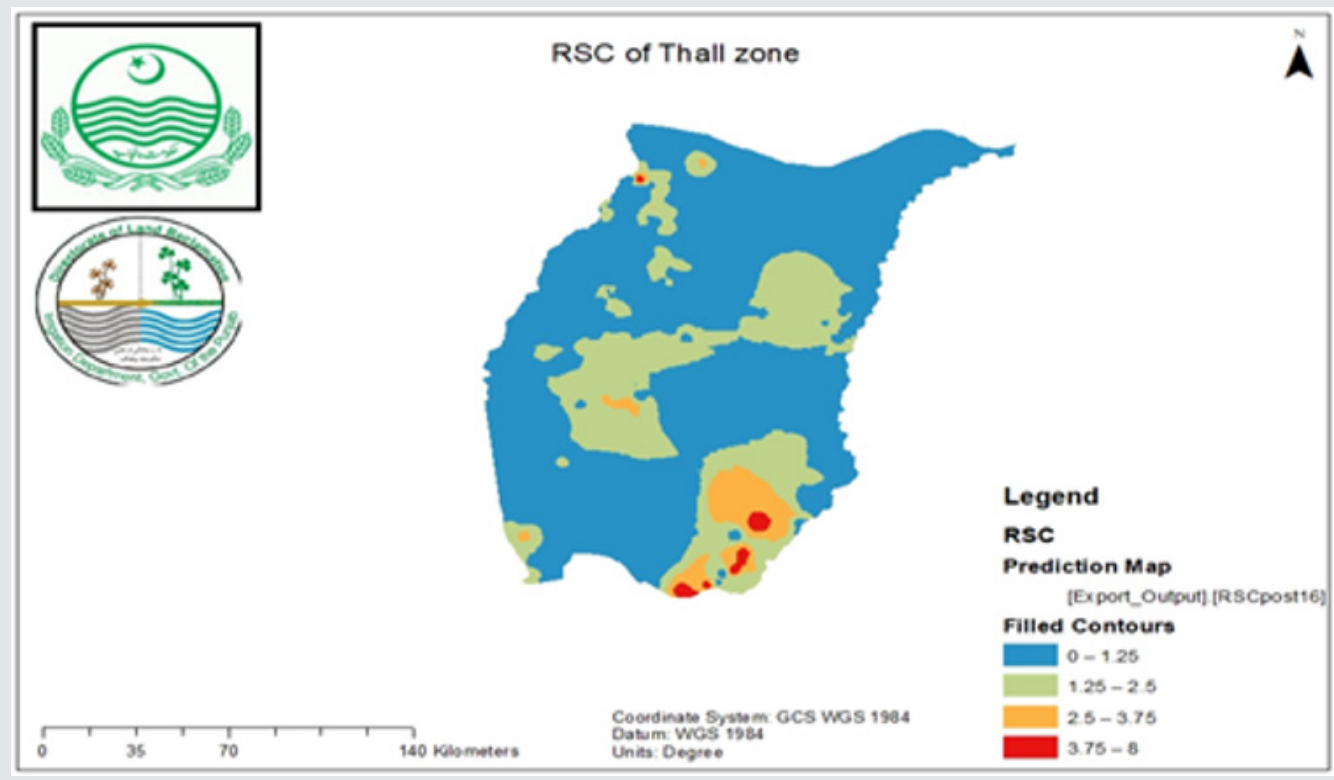

Figures 3: GPS map of the quality points with respect toRSC in the Thal area.

The application of brackish water directly causes buildup of salts to an unacceptable limit with concurrent heavy reduction in crop yields. This scenario could be reduced by suitable management of irrigation water before its usage. The agronomic measures including deep tillage practices, addition of soil amendments, use of salt-tolerant varieties, growing crops on ridges, alternatively proper mixing of brackish water with quality graded water and/ or alternate watering of crops with brackish and quality water. The salt tolerant crops, for example wheat, rice, barley, sorghum and fruit trees for example guava, citrus, dates, and blueberry could be irrigated with marginally unfit waters. The poor-quality irrigation water may also be used for growing timbers e.g. trees Eucalyptus, Acacia and Atriplex spp. for grazing purpose in Thal area $[8,18]$.

The water having substantial SAR and RSC may be ignored for crop growth. This is because, ground water bearing significant amounts of sodium, carbonates and bicarbonates enhance the development of salinization, and at the same time disturbing the soil hydraulic and permeability [19]. Mostly, where the source of irrigation water is exclusively reliant upon the brackish water, then special water treatments and farm management operations required to be done to moderate the lethal impacts of salts $[20,21]$. The negative effects of RSC and SAR containing irrigation water could be reduced by addition of gypsum $\left(\mathrm{CaSO}_{4} \cdot 2 \mathrm{H}_{2} \mathrm{O}\right)$, commercial sulphuric acid $\left(\mathrm{H}_{2} \mathrm{SO}_{4}\right)$ and acid forming amendments either in soil or water $[7,8]$. The application of organic material (pressmud, poultry manure, farmyard manure), deep ploughing and cultivation of salt-tolerant crop varieties are being engaged and encouraged to restructure the toxic effects of brackish water $[8,20]$. These practices may be carried out periodically to avoid economic yield losses in the area [22-24].

\section{Conclusion}

The field survey conducted in Thal area revealed that a sufficient number $(47 \%)$ of tube wells extracted marginal to unfit water for irrigation purpose. The groundwater is considered unfit mainly due to higher values of electrical conductivity, and cumulative effect of EC and SAR. The quality of ground water underlined by hard pan of calcium carbonate coupled with saline nature of parent material is generally unfit for irrigation. Substantial number of tube wells installed in the study area accelerates discharge component thereby causing the dissolved salts upward direction making the soil saline.

\section{References}

1. Qasim M, S Khalid, D Farhan Shams (2014) Spatiotemporal varieties and trends in minimum \& maximum temperatures of Pakistan. J Appl Environ Biol Sci 4(8S): 85-93.

2. Umair R, Z Abbas, Q Zaman, M Mubashir, M Jabeen, et al. (2018) Evaluation of groundwater quality for irrigation purpose and effect on crop yields. A GIS based study of Bahawalpur. Pak J Agri Res 31(1): 2936.

3. Ishaq M, SM Mehdi, M Jamil, AA Rahi, MQ Masood (2016) Irrigation quality status of tube well waters and management of sustained crop production in canal command area of district Sahiwal. J Agric Res 54(3): 383-393.

4. Ahmad N, MA Ali, MK Rashid, S Noreen, B Butt (2015) Irrigation quality of underground water in district Multan. Pak J Agri Agril Engg Vet Sci 31(2): 211-220. 
5. Ashraf M, MB Khan, F Umar (2018) Characterization of groundwater quality for irrigation in Tehsil and District Layyah, Punjab Pakistan. World Rural Observ 10(3):74-78.

6. Pervaiz Z, SSH Kazmi, KH Gill (2003) Characterization of groundwater in Gujrat district. Pak J Soil Sci 22: 48-54.

7. Ali MS, S Mahmood, MN Chaudhry, M Sadiq (2009) Irrigation quality of ground water of twenty villages in Lahore district. Soil Environ 28(1): 17-23.

8. Mehboob M, S Shakir, A Mehboob (2011) Surveying tube well water suitability for irrigation in four tehsils of district Kasur. Soil Environ 30(2): 155-159.

9. Rhodes D, A Nadolska Orczyk, PJ Rich (2002) Salinity, osmolytes and compatible solutes. In: Lauchli A, U Luttge (eds) Salinity: EnvironmentPlants-Molecules. Kluwer, Dordrecht, Netherlands. pp. 181-204.

10. Zhu JK (2002) Salt and drought stress signal transduction in plants. Ann Rev Plant Biol 53: 247-273.

11. Burman U, BK Grag, S Katthju (2003) Water relations, photosynthesis and nitrogen metabolism of Indian mustard (Brassica junceaCzron. and Con) grown under salt and water stress. J Plant Biol 30: 55-60.

12. Page AL, RH Miller, DR Keeney (1982) Methods of Soil Analysis Part II, $2^{\text {nd }}$ edn. American Society of Agronomy. No. 9. Madison, Wisconsin, USA

13. Dash A, Das HK, Mishra B (2014) Hydrogeochemistry and ground water quality in and around Joda of Keonjhar district, Odisha, India. IJISR 12(2): 409-419.

14. Hagras MA (2013) Water quality assessment and hydrochemical characteristics of groundwater in Punjab, Pakistan. IJRRAS 16(2).
15. Bennetts DA, JA Webb, M McCaskill, R Zollinger (2007) Dryland salinity processes within the discharge zone of a local groundwater system, southeastern Australia. Hydrogeology J 15: 1197-1210.

16. Shakir MS, M Ahmed, MA Khan (2002) Irrigational quality of underground water in Kasur district. Asian J Plant Sci 1: 53-54.

17. Hannan, Iqbal (2012) Groundwater leveland quality monitoring in Piunjab. Annual Report. Directorate of Land Reclamation Punjab, Lahore, Pakistan.

18. Waheed A, R Khalid, T Mahmood, MT Siddique, AS Javed (2010) Quality of groundwater for irrigation in tehsil Texila of district Rawalpindi, Punjab. Soil Environ 29(2): 167-171.

19. Ghafoor A, M Qadir, G Murtaza (2002) Agriculture in the Indus Plains: Sustainability of Land and Water resources: A Review. Int J Agric Biol 4(3): 428-437.

20. Ashraf M, Rahmatullah, MA Gill (2005) Irrigation of crops with brackish water using organic amendments. Pak J Agric Sci 42(1-2): 33-37.

21. Keshavarzi A, H Etesami, M Jamei, M Nadi (2010) Effect of indiscriminate removing ground water on irrigation water's salinity in arid area, Central Iran. Austr J Basic Appl Sci 4(10): 5283-5290.

22. Malik DM, MA Khan, TA Chaudhry (1984) Analysis manual for soils, plants and water. Soil Fertility Survey and Soil Testing Institute, Lahore, Pakistan, pp. 74

23. Rashid A (1996) Nutrient indexing of cotton and boron and zinc nutrition of cotton. NARC, Islamabad, Pakistan, pp. 76

24. Steel RGD, JH Torrie (1980) Principles and Procedures of Statistics. A biometrical approach, $2^{\text {nd }}$ edn., McGraw-Hill Book Company, New York, USA.

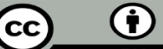

This work is licensed under Creative Commons Attribution 4.0 License

To Submit Your Article Click Here: Submit Article

DOI: 10.32474/CIACR.2018.05.000225

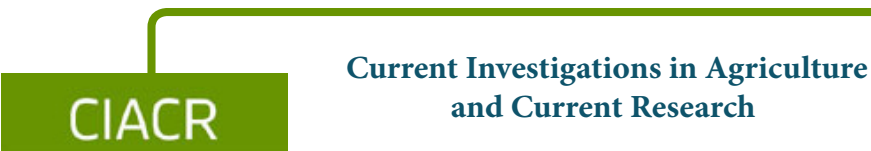

\section{Assets of Publishing with us}

- Global archiving of articles

- Immediate, unrestricted online access

- Rigorous Peer Review Process

- Authors Retain Copyrights

- Unique DOI for all articles 